\title{
Recent Development in Carbohydrate-Based Cancer Vaccines
}

\author{
Zhongwu Guo* and Qianli Wang \\ Department of Chemistry, Wayne State University, 5101 Cass Avenue, Detroit, MI 48202, USA
}

\section{Summary}

Tumor-associated carbohydrate antigens (TACAs) are important molecular markers on the cancer cell surface, useful for the development of therapeutic cancer vaccines or cancer immunotherapies. However, due to their poor immunogenicity and/or immunotolerance, most TACAs fail to induce T cell-mediated immunity that is critical for cancer therapy. This review summarizes the recent effort to overcome this problem via constructing TACA conjugates with improved immunogenicity, such as by covalently coupling TACAs to proper carrier molecules to form clustered or multi-epitopic conjugate vaccines, coupling TACAs to a T cell peptide epitope and/or an immunostimulant epitope to form fully synthetic multi-component glycoconjugate vaccines, and developing vaccines based on chemically modified TACAs, which is combined with metabolic engineering of cancer cells.

\section{Keywords}

cancer immunotherapy; cancer vaccine; tumor-associated carbohydrate antigen; immunotolerance; glycoconjugate; glycoprotein; glycoengineering

\section{Introduction}

Cancer immunotherapy has attracted significant attention recently, because of its potential as a highly potent and specific cancer cure. Immunotherapy aims to elicit the patient's immune system to eradicate cancer by using an antibody that can specifically target cancer or a vaccine that can provoke a specific immune response against cancer. For this purpose, the glycans uniquely or excessively expressed by tumors, known as tumor-associated carbohydrate antigens (TACAs) [1], are useful targets, because TACAs are abundant and exposed on the cancer cell surface [2] and are correlated with various stages of cancer development [1].

However, a serious problem associated with TACAs is that they are usually poorly immunogenic and induce $\mathrm{T}$ cell-independent immune response [3], while $\mathrm{T}$ cell-mediated immunity is critical for cancer immunotherapy [4]. Another issue is that most TACAs are tolerated by the patient's immune system [5]. Though the exact mechanism for immunotolerance is not fully understood, a low level of expression of TACAs in normal tissues or at a specific development stage [6] and their structural similarity to normal antigens [7] are at least partially responsible. In fact, instead of being tumor-specific, most TACAs are either excessively expressed "self" glycans or their biosynthetic intermediates. It is thus difficult to create effective vaccines from TACAs. This review has summarized the recent (in the past two

\footnotetext{
*Correspondence author. Phone: 313-577-2557, Fax: 313-577-8822, zwguo@chem.wayne.edu.

Publisher's Disclaimer: This is a PDF file of an unedited manuscript that has been accepted for publication. As a service to our customers we are providing this early version of the manuscript. The manuscript will undergo copyediting, typesetting, and review of the resulting proof before it is published in its final citable form. Please note that during the production process errors may be discovered which could affect the content, and all legal disclaimers that apply to the journal pertain.
} 
to three years) efforts for overcoming these problems and for the development of TACA-based cancer vaccines. Several recent reviews have covered different aspects in the area [8-11].

\section{Semi-synthetic glycoconjugate cancer vaccines}

It has been established that covalently coupling carbohydrates to an immunologically active protein can remarkably improve their immunogenicity and convert them from $\mathrm{T}$ cellindependent antigens to $\mathrm{T}$ cell-dependent ones [3]. Consequently, a widely adopted principle for the design of carbohydrate-based cancer vaccines is to link TACAs to a carrier protein to form semi-synthetic glycoproteins. Livingston and Danishefsky [12] have shown that keyhole limpet haemocyanin $(\mathrm{KLH})$ is the most effective TACA carrier. It has also been demonstrated that the linker used to conjugate carbohydrates and proteins can have a major impact on the immunological properties of resultant conjugates. For example, some linkers may provoke antibodies, while others may suppress the immune response to the target antigen [13,14]. Therefore, it is important to use immunologically inactive linkers for the construction of TACA-based cancer vaccines [15].

According to the number and type of TACAs attached to a carrier protein, glycoconjugate cancer vaccines can be classified into: (1) mono-epitopic vaccines containing a single type of TACA; (2) mono-epitopic cluster vaccines containing clusters of one type of TACA; and (3) multi-epitopic vaccines containing several types of TACAs. Mono-epitopic conjugate vaccines are the most extensively explored, of which many have reached the stage of clinical trials [16]. For example, the KLH conjugates of GM2 [17] and sTn [18] (Figure 1) have both entered phase III clinical trials. Unfortunately, no vaccine has met the endpoint of time-to-disease progression and overall survival in clinical trials yet, mainly because they typically elicit B cell-mediated immunity rather than T cell-mediated immunity in cancer patients [18].

Since antibodies provoked by mono-epitopic vaccines did not react well with TACAs [19, 20], especially mucin-related TACAs, which often present in clusters on the tumor cell surface [21], much recent effort has been focusing on a vaccine design consisting of TACA clusters [20]. A Phase I clinical trial of Tn(c)-KLH conjugate (Figure 2) alone with a saponin adjuvant QS-21 showed that the levels of prostate specific antigen (PSA) in the treated prostate cancer patients either stabilized or declined [22]. A Phase I clinical trial of TF(c)-KLH/QS-21 in patients with biochemically relapsed prostate cancer also showed antitumor effects [23]. Recently, a KLH conjugate of Gb3 (Gb3-MUC5AC(c)-KLH, Figure 2) with a peptide MUC5AC derived from mucins as the linker and a tumor marker was prepared [24], which was expected to induce a strong immune response against both Gb3 and MUC5AC. Moreover, MUC5AC can act as a helper T (Th) cell epitope to assist the activation of T cells as well.

As tumors can have multiple TACAs at their cell surface and express different level and nature of antigens at each stage of development, the design of multi-epitopic cancer vaccines is desirable for targeting a population of transformed cells [25]. One approach to achieve this goal is to use a mixture of several mono-epitopic vaccines. Co-administration of GD3-KLH, $\mathrm{Le}^{\mathrm{y}}-\mathrm{KLH}, \mathrm{MUC1}-\mathrm{KLH}$ and MUC2-KLH along with QS-21 was demonstrated to induce high titers of $\operatorname{IgM}$ and $\mathrm{IgG}$ antibodies that reacted specifically with the individual antigens [26]. Similar results were obtained with a mixture of GM2-KLH, Globo H-KLH, Le ${ }^{\mathrm{y}}-\mathrm{KLH}, \mathrm{TF}(\mathrm{c})$ $\mathrm{KLH}, \mathrm{Tn}(\mathrm{c})-\mathrm{KLH}, \mathrm{sTn}(\mathrm{c})-\mathrm{KLH}$, and glycosylated MUC1-KLH [27]. Based on these results, a Phase II clinical trial was initiated in breast, ovarian and prostate cancer patients. However, this approach requires the use of increased amounts of carrier proteins, and each vaccine component has to be validated. To address these issues, multi-epitopic vaccines were synthesized and studied [28]. The KLH conjugate of Tn, Le ${ }^{\mathrm{y}}$ and Globo H [28] was found to provoke both IgM and IgG antibodies against individual TACAs. Similar results were obtained 
with highly elaborated multi-epitopic vaccines [29,30], such as the KLH conjugate of Globo $\mathrm{H}, \mathrm{Le}^{\mathrm{y}}$, sTn, Tn and TF (Figure 3).

\section{Fully synthetic glycoconjugate cancer vaccines}

Although promising, semi-synthetic vaccines have some limitations [31], because of the ambiguous composition and structure of the conjugates and adjuvants, as well as the irrelevant antibody production against carriers [13]. To address these issues, fully synthetic homogeneous vaccines are pursued, which can also be designed to contain an adjuvant or other immunological epitopes to further enhance the immunogenicity of resulting vaccines.

The first example demonstrating that a synthetic carbohydrate vaccine can generate a robust immune response without the use of a protein carrier or external adjuvant was described by Toyokuni et al [32]. Their vaccine (di-Tn-Pam3Cys, Figure 4) was composed of a dimeric Tn epitope and an immunologically active lipopeptide, tripalmitoyl-S-glyceryl-cysteinylserine (Pam3Cys), derived from the $N$-terminal sequence of an E. coli lipoprotein. Later, Kudryashov et al [33] prepared several Pam3Cys-based Le ${ }^{\mathrm{y}}$ conjugates (Figure 4) and examined the impact of epitope clustering, carrier structure, and adjuvant on the vaccines. They demonstrated that the conjugate containing a cluster of three contiguous $\mathrm{Le}^{\mathrm{y}}$ epitopes was superior to the one containing a single $\mathrm{Le}^{\mathrm{y}}$ epitope.

Two-component glycopeptide vaccines containing a B cell epitope and a T cell peptide epitope were also examined. Immunological studies of glycopeptides consisting of Tn or GM2 antigen and a poliovirus (PV) $\mathrm{CD}^{+} \mathrm{T}$ cell epitope showed that short glycopeptides were able to induce anticancer antibody responses [34,35]. Kunz and co-workers [36] revealed that both the glycan and the peptide backbone were important for the epitope recognition. Moreover, Lo-Man et al $[37,38]$ found that both the clustering and presentation of Tn are important parameters for dendrimeric multiple antigenic $O$-glycopeptide (MAG) vaccines MAG:Tn-PV and MAG:Tn3PV (Figure 5) carrying Tn antigen and PV T cell epitope. The MAG template was also used to construct $\mathrm{Tn}$ vaccines containing a tetanus toxin (TT)-derived peptide and a non-natural Th epitope, the Pan-HLA-DR-binding epitope (PADRE). Both MAG:Tn3-TT and MAG: $\operatorname{Tn}(\mathrm{S}) 3$ PADRE provoked strong IgG antibodies capable of mediating cytotoxicity against Tn-positive human tumor cells [38]. Dumy and co-workers [39] examined the regioselectively addressable functionalized templates (RAFTs) for multi-epitopic glycopeptide vaccine construction.

Studies on RAFT-Tn4-1PV and RAFT-Tn4-2PV (Figure 5) proved that RAFT is a nonimmunogenic and functional vaccine carrier, which opens new perspectives for TACAbased vaccine development.

Because the above fully synthetic two-component vaccines either provoked a low level of IgG response due to the lack of $\mathrm{T}$ cell-stimulating epitopes (Pam3Cys conjugates) or needed an external adjuvant (glycopeptides), Boons and co-workers [40] explored a new three-component vaccine design consisting of a B cell epitope (TACA), an adjuvant, and a Th epitope. A vaccine made of a tumor-associated MUC1 glycopeptide, a mouse MHC class II restricted PV Th epitope, and a built-in adjuvant (Pam2CysSK4 or Pam3CysSK4) (Figure 6) elicited an exceptionally high titer of IgG antibody that recognized MUC1-expressing cancer cells [41]. Renaudet et al [42] recently constructed a four-component vaccine based on RAFT (Figure 6), which contained a cluster of $\mathrm{Tn}$ antigen, a $\mathrm{CD} 4^{+} \mathrm{Th}$ peptide epitope (PADRE), a CD8 ${ }^{+} \mathrm{CTL}$ peptide epitope (OVA $257-264)$, and a built-in immunoadjuvant (Pam3Cys). This vaccine elicited robust $\mathrm{Tn}$-specific IgG/IgM antibodies. In addition, it induced strong PADRE-specific $\mathrm{CD}^{+} \mathrm{T}$ cell and $\mathrm{OVA}_{257-264}$-specific $\mathrm{CD} 8^{+} \mathrm{T}$ cell responses, highlighting correct antigen processing and presentation of both Th and CTL epitopes. Immunization with this vaccine resulted in the reduction of tumor size in mice inoculated with murine MO5 cancer cells, protection of mice from lethal cancer cell challenge, and inhibition of pre-established MO5 
tumor growth [43]. These results suggested the potential of self-adjuvanting glycolipopeptides as a platform for $\mathrm{B}$ cell, $\mathrm{CD} 4^{+}$and $\mathrm{CD} 8^{+} \mathrm{T}$ cell epitope-based cancer vaccines.

\section{Cell glycoengineering-based cancer immunotherapy}

Despite the aforementioned progress, most vaccines made of natural TACAs failed finally, mainly because of the lack of a robust $\mathrm{T}$ cell-mediated immunity. It is conceivable that unnatural TACA analogues may be more immunogenic than natural TACAs and be able to induce $\mathrm{T}$ cell-mediated immunity required for successful cancer therapy. Earlier studies proved that unnatural TACA analogues were indeed highly immunogenic and induced both IgM and IgG antibodies $[44,45]$. However, since the immunotherapy had to rely on cross-reactivity between the elicited antibodies or immune system against the unnatural TACA analogue and the natural TACA on cancer cells, the therapeutic efficacy was significantly compromised.

To overcome the above problems, Guo and coworkers [46,47] developed a novel immunotherapeutic strategy, which combined cell glycoengineering [48] with vaccines made of unnatural TACA analogues. It design principle is shown in Figure 7. For active cancer immunotherapy (Figure 7A), after patients are inoculated with a synthetic vaccine, tumors can be glycoengineered to express the TACA analogue in place of the natural TACA. Subsequently, the provoked immune system would specifically recognize and kill cancer. For passive cancer immunotherapy, namely, treatment with antibody (Figure 7B), patients would be first treated with an unnatural precursor of the target TACA to glycoengineer cancer cells and then treated with a specific antibody prepared by immunization of a healthy individual using the synthetic vaccine. With GM3 and sTn as target antigens, Guo and coworkers [46,49] have demonstrated that on the treatment with a low $\mu \mathrm{M}$ concentration of $N$-phenylacetyl-D-mannosamine (ManNPhAc) an array of cancer cells were efficiently engineered to express unnatural GM3 and sTn analogues, that is $N$-phenylacetyl GM3 (GM3NPhAc) and sTn (sTnNPhAc) [50,51], respectively (Figure 8). They have also shown that GM3NPhAc and sTnNPhAc can form potent vaccines that induced strong and durable $\mathrm{T}$ cell-mediated immune responses. It was further disclosed that GM3NPhAc-KLH-induced antisera and GM3NPhAc-specific mAb exhibited strong and specific CDC to several melanoma cell lines following treatment with ManNPhAc [50,51], while normal cells were not affected under the same conditions. These results suggested a new and highly selective cancer immunotherapy [52]. This strategy was also verified by using 2,8-polysialic acid (PSialA) as the target antigen. It was observed that mAb 13D9, an antibody specific to $N$-propionyl-polysialic acid (PSialANPr), showed strong and specific CDC to RMA cell treated with $N$-propionyl-D-mannosamine (ManNPr), the biosynthetic precursor of PSialANPr, and that the administration of mAb 13D9 and ManNPr to mice could inhibit established RMA tumor growth and metastasis [47]. Jennings and coworkers [53] proved that a GD3NBu-specific mAb 2A could selectively lyse GD3expressing SKMEL-28 cells treated with $N$-butanoyl-D-mannosamine (ManNBu) and that $\mathrm{mAb} 2 \mathrm{~A} / \mathrm{ManNBu}$ treatment could protect mice from SKMEL-28 tumor grafting. However, the feasibility and the therapeutic efficacy of the new strategy, particularly its selectivity for tumors in vivo, need to be verified further.

\section{Conclusion}

The potential of TACA-based cancer vaccines has been well documented, and a number of vaccines have entered clinical trials, including Phase III clinical trials. However, up to date, no TACA-based cancer vaccine has been approved for clinical use yet. The failures are mainly due to the absence of $\mathrm{T}$ cell-mediated immune response in cancer patients. To further augment the immunogenicity of TACAs, fully synthetic vaccines incorporating a CD4 ${ }^{+} \mathrm{Th}$ and/or $\mathrm{CD} 8^{+} \mathrm{CTL}$ peptide epitope and an immunostimulant are being actively pursued. This design has been proved helpful for inducing T cell-mediated antitumor immunity. Moreover, fully 
synthetic conjugates will enable structure-activity relationship (SAR) studies for the discovery of more effective vaccines. We are optimistic that this area will witness significant growth in the future with synthetic glycoconjugates becoming more and more easily available. Another exciting direction in cancer immunotherapy is the combination of synthetic conjugate vaccines made of unnatural TACA analogues and cancer cell glycoengineering. Since many TACAs are sialo-TACAs with sialic acid at the non-reducing end, this forefront location of sialic acid and the important role it plays in oncogenesis [54,55] make the new immunotherapeutic strategy particularly attractive and potentially broadly useful. Finally, the marriage of this strategy with other strategies in the field may provide new growth points in the development of efficient cancer immunotherapies.

\section{Acknowledgments}

Our research on cancer vaccines and cancer immunotherapies is supported by National Institutes of Health/National Cancer Institute (CA95142). We thank Benjamin M. Swarts for proofreading this manuscript.

\section{References}

1. Hakomori S. Tumor-associated carbohydrate antigens defining tumor malignancy: Basis for development of anti-cancer vaccines. Adv Exp Med Biol 2001;491:369-402. [PubMed: 14533809]

2. Ragupathi G. Carbohydrate antigens as targets for active specific immunotherapy. Cancer Immunol Immunother 1996;43:152-157. [PubMed: 9001568]

3. Jennings, HJ.; Sood, RK. Synthetic glycoconjugates as human vaccines. In: Lee, YC.; Lee, RT., editors. Neoglycoconjugates: Preparation and Applications. Academic Press; 1994. p. 325-371.

4. Chen $\mathrm{CH}$, Wu TC. Experimental vaccine strategies for cancer immunotherapy. J Biomed Sci 1998;5:231-252. [PubMed: 9691216]

5. Ochsenbein AF, Klenerman P, Karrer U, Ludewig B, Pericin M, Hengartner H, Zinkernagel RM. Immune surveillance against a solid tumor fails because of immunological ignorance. Proc Natl Acad Sci USA 1999;96:2233-2238. [PubMed: 10051624]

6. Zinkernagel RM. Localization dose and time of antigens determine immune reactivity. Semin Immunol 2000;12:163-171. [PubMed: 10910735]

7. Livingston PO. Approaches to augmenting the immunogenicity of melanoma gangliosides: from whole melanoma cells to ganglioside-KLH conjugate vaccines. Immunol Rev 1995;145:147-166. [PubMed: 7590824]

8. Cipolla L, Peri F, Airoldi C. Glycoconjugates in cancer therapy. Anticancer Agents Med Chem 2008;8:92-121. [PubMed: 18220509]

9. Freire T, Bay S, Vichier-Guerre S, Lo-Man R, Leclerc C. Carbohydrate antigens: synthesis aspects and immunological applications in cancer. Mini Rev Med Chem 2006;6:1357-1373. [PubMed: 17168812]

10. Slovin SF, Keding SJ, Ragupathi G. Carbohydrate vaccines as immunotherapy for cancer. Immunol Cell Biol 2005;83:418-428. [PubMed: 16033538]

11. Warren, JD.; Geng, XD.; Danishefsky, SJ. Synthetic glycopeptide-based vaccines. In: Wittmann, V., editor. Glycopeptides and Glycoproteins: Synthesis, Structure, and Application. Springer; 2007. p. 109-141.

12. Kagan E, Ragupathi G, Yi SS, Reis CA, Gildersleeve J, Kahne D, Clausen H, Danishefsky SJ, Livingston PO. Comparison of antigen constructs and carrier molecules for augmenting the immunogenicity of the monosaccharide epithelial cancer antigen Tn. Cancer Immunol Immunother 2005;54:424-430. [PubMed: 15625606]• Immunological properties of glycoconjugate vaccines containing different carrier proteins were compared to establish that KLH is a superior carrier.

13. Schutze MP, Leclerc C, Jolivet M, Audibert F, Chedid L. Carrier-induced epitopic suppression, a major issue for future synthetic vaccines. J Immunol 1985;135:2319-2322. [PubMed: 2411793]

14. Buskas T, Li Y, Boons GJ. The immunogenicity of the tumor-associated antigen Lewis(y) may be suppressed by a bifunctional cross-linker required for coupling to a carrier protein. Chemistry 2004;10:3517-3524. [PubMed: 15252797] 
15. Wang Q, Ekanayaka SA, Wu J, Zhang J, Guo Z. Synthetic and immunological studies of 5'-Nphenylacetyl sTn to develop carbohydrate-based cancer vaccines and to explore the impacts of linkage between carbohydrate antigens and carrier proteins. Bioconjug Chem 2008;19:2060-2067. [PubMed: 18816108]

16. Franco A. Glycoconjugates as vaccines for cancer immunotherapy: clinical trials and future directions. Anticancer Agents Med Chem 2008;8:86-91. [PubMed: 18220508]

17. Chapman PB, Morrissey DM, Panageas KS, Hamilton WB, Zhan C, Destro AN, Williams L, Israel RJ, Livingston PO. Induction of antibodies against GM2 ganglioside by immunizing melanoma patients using GM2-keyhole limpet hemocyanin + QS21 vaccine: a dose-response study. Clin Cancer Res 2000;6:874-879. [PubMed: 10741710]

18. Holmberg LA, Sandmaier BM. Vaccination with Theratope (STn-KLH) as treatment for breast cancer. Expert Rev Vaccines 2004;3:655-663. [PubMed: 15606349]

19. Adluri S, Helling F, Ogata S, Zhang S, Itzkowitz SH, Lloyd KO, Livingston PO. Immunogenicity of synthetic TF-KLH (keyhole limpet hemocyanin) and sTn-KLH conjugates in colorectal carcinoma patients. Cancer Immunol Immunother 1995;41:185-192. [PubMed: 7553688]

20. Zhang S, Walberg LA, Ogata S, Itzkowitz SH, Koganty RR, Reddish M, Gandhi SS, Longenecker $\mathrm{BM}$, Lloyd KO, Livingston PO. Immune sera and monoclonal antibodies define two configurations for the sialyl Tn tumor antigen. Cancer Res 1995;55:3364-3368. [PubMed: 7614472]

21. Carlstedt I, Davies JR. Glycoconjugates facing the outside world. Biochem Soc Trans 1997;25:214219. [PubMed: 9056873]

22. Slovin SF, Ragupathi G, Musselli C, Olkiewicz K, Verbel D, Kuduk SD, Schwarz JB, Sames D, Danishefsky S, Livingston PO, et al. Fully synthetic carbohydrate-based vaccines in biochemically relapsed prostate cancer: clinical trial results with alpha- $\mathrm{N}$-acetylgalactosamine-O-serine/threonine conjugate vaccine. J Clin Oncol 2003;21:4292-4298. [PubMed: 14645418]

23. Slovin SF, Ragupathi G, Musselli C, Fernandez C, Diani M, Verbel D, Danishefsky S, Livingston P, Scher HI. Thomsen-Friedenreich (TF) antigen as a target for prostate cancer vaccine: clinical trial results with TF cluster (c)-KLH plus QS21 conjugate vaccine in patients with biochemically relapsed prostate cancer. Cancer Immunol Immunother 2005;54:694-702. [PubMed: 15726361]

24. Zhu J, Wan Q, Ragupathi G, George CM, Livingston PO, Danishefsky SJ. Biologics through chemistry: total synthesis of a proposed dual-acting vaccine targeting ovarian cancer by orchestration of oligosaccharide and polypeptide domains. J Am Chem Soc 2009;131:4151-4158. [PubMed: 19253940]• A multi-component conjugate vaccine of Gb3 with a peptide MUC5AC derived from mucins as linker and a tumor marker was prepared. MUC5AC was also a helper T (Th) cell epitope that would assist the activation of $\mathrm{T}$ cells.

25. Livingston P. The unfulfilled promise of melanoma vaccines. Clin Cancer Res 2001;7:1837-1838. [PubMed: 11448892]

26. Ragupathi G, Cappello S, Yi SS, Canter D, Spassova M, Bornmann WG, Danishefsky SJ, Livingston PO. Comparison of antibody titers after immunization with monovalent or tetravalent KLH conjugate vaccines. Vaccine 2002;20:1030-1038. [PubMed: 11803062]

27. Ragupathi G, Koide F, Sathyan N, Kagan E, Spassova M, Bornmann W, Gregor P, Reis CA, Clausen $\mathrm{H}$, Danishefsky SJ, et al. A preclinical study comparing approaches for augmenting the immunogenicity of a heptavalent KLH-conjugate vaccine against epithelial cancers. Cancer Immunol Immunother 2003;52:608-616. [PubMed: 12811527]

28. Allen JR, Harris CR, Danishefsky SJ. Pursuit of optimal carbohydrate-based anticancer vaccines: preparation of a multiantigenic unimolecular glycopeptide containing the Tn, MBr1, and Lewis(y) antigens. J Am Chem Soc 2001;123:1890-1897. [PubMed: 11456809]

29. Keding SJ, Danishefsky SJ. Prospects for total synthesis: a vision for a totally synthetic vaccine targeting epithelial tumors. Proc Natl Acad Sci U S A 2004;101:11937-11942. [PubMed: 15280546]

30. Ragupathi G, Koide F, Livingston PO, Cho YS, Endo A, Wan Q, Spassova MK, Keding SJ, Allen J, Ouerfelli $\mathrm{O}$, et al. Preparation and evaluation of unimolecular pentavalent and hexavalent antigenic constructs targeting prostate and breast cancer: a synthetic route to anticancer vaccine candidates. $\mathrm{J}$ Am Chem Soc 2006;128:2715-2725. [PubMed: 16492059]•• A highly elaborated multi-epitopic vaccine was prepared and was shown to provoke antibodies against individual TACAs. 
31. Roy, R. New trends in carbohydrate-based vaccines. In: Owens, J., editor. Drug Discovery Today: Technologies. Vol. 1. Elsevier Science Ltd.; 2004. p. 327-336.

32. Toyokuni T, Dean B, Cai SP, Boivin D, Hakomori S, Singhal AK. Synthetic Vaccines - Synthesis of a Dimeric Tn Antigen-Lipopeptide Conjugate That Elicits Immune-Responses against TnExpressing Glycoproteins. J Am Chem Soc 1994;116:395-396.

33. Kudryashov V, Glunz PW, Williams LJ, Hintermann S, Danishefsky SJ, Lloyd KO. Toward optimized carbohydrate-based anticancer vaccines: epitope clustering, carrier structure, and adjuvant all influence antibody responses to Lewis(y) conjugates in mice. Proc Natl Acad Sci U S A 2001;98:3264-3269. [PubMed: 11248067]

34. Vichier-Guerre S, Lo-Man R, Bay S, Deriaud E, Nakada H, Leclerc C, Cantacuzene D. Short synthetic glycopeptides successfully induce antibody responses to carcinoma-associated Tn antigen. J Pept Res 2000;55:173-180. [PubMed: 10784033]

35. Bay S, Fort S, Birikaki L, Ganneau C, Samain E, Coic YM, Bonhomme F, Deriaud E, Leclerc C, LoMan R. Induction of a Melanoma-Specific Antibody Response by a Monovalent, but not a Divalent, Synthetic GM2 Neoglycopeptide. ChemMedChem 2009;4:582-587. [PubMed: 19226501]

36. Westerlind U, Hobel A, Gaidzik N, Schmitt E, Kunz H. Synthetic vaccines consisting of tumorassociated MUC1 glycopeptide antigens and a T-cell epitope for the induction of a highly specific humoral immune response. Angew Chem Int Ed Engl 2008;47:7551-7556. [PubMed: 18704911]• This paper has revealed that both the B cell glycan epitope and the T cell peptide epitope of twocomponent glycopeptide vaccines were important for the immune response and TACA epitope recognition.

37. Lo-Man R, Vichier-Guerre S, Bay S, Deriaud E, Cantacuzene D, Leclerc C. Anti-tumor immunity provided by a synthetic multiple antigenic glycopeptide displaying a tri-Tn glycotope. J Immunol 2001;166:2849-2854. [PubMed: 11160353]

38. Lo-Man R, Vichier-Guerre S, Perraut R, Deriaud E, Huteau V, BenMohamed L, Diop OM, Livingston PO, Bay S, Leclerc C. A fully synthetic therapeutic vaccine candidate targeting carcinoma-associated Tn carbohydrate antigen induces tumor-specific antibodies in nonhuman primates. Cancer Res 2004;64:4987-4994. [PubMed: 15256473]• This paper reported that both the clustering and presentation of Tn are important parameters for dendrimeric multiple antigenic O-glycopeptide vaccines.

39. Grigalevicius S, Chierici S, Renaudet O, Lo-Man R, Deriaud E, Leclerc C, Dumy P. Chemoselective assembly and immunological evaluation of multiepitopic glycoconjugates bearing clustered $\mathrm{Tn}$ antigen as synthetic anticancer vaccines. Bioconjugate Chem 2005;16:1149-1159.

40. Buskas T, Ingale S, Boons GJ. Towards a fully synthetic carbohydrate-based anticancer vaccine: synthesis and immunological evaluation of a lipidated glycopeptide containing the tumor-associated tn antigen. Angew Chem Int Ed Engl 2005;44:5985-5988. [PubMed: 16108081]• This is the first report of a three-component vaccine consisting of a B cell epitope - a TACA, an adjuvant, and a Th epitope.

41. Ingale S, Wolfert MA, Buskas T, Boons GJ. Increasing the antigenicity of synthetic tumor-associated carbohydrate antigens by targeting Toll-like receptors. Chembiochem 2009;10:455-463. [PubMed: 19145607]•• A three-component vaccine made of a tumor-associated MUC1 glycopeptide, a mouse MHC class II restricted Th epitope, and a built-in adjuvant elicited an exceptionally high titer of IgG antibody that recognized MUC1-expressing cancer cells.

42. Renaudet O, BenMohamed L, Dasgupta G, Bettahi I, Dumy P. Towards a self-adjuvanting multiepitopic B and T cell epitope containing synthetic glycolipopeptide cancer vaccine. ChemMedChem 2008;3:737-741. [PubMed: 18205167]•• This paper reported a four-component vaccine consisting of a cluster of $\mathrm{Tn}$ antigen, a CD4 ${ }^{+}$Th peptide epitope, a CD8 ${ }^{+} \mathrm{CTL}$ peptide epitope, and a built-in immunoadjuvant. It was shown to elicit Tn-specific IgG/IgM antibodies and robust $\mathrm{CD}^{+}$and $\mathrm{CD} 8^{+} \mathrm{T}$ cell responses, highlighting correct antigen processing and presentation of both Th and CTL epitopes.

43. Bettahi I, Dasgupta G, Renaudet O, Chentoufi AA, Zhang X, Carpenter D, Yoon S, Dumy P, BenMohamed L. Antitumor activity of a self-adjuvanting glyco-lipopeptide vaccine bearing B cell, CD4+ and CD8+ T cell epitopes. Cancer Immunol Immunother 2009;58:187-200. [PubMed: 18584174]•• Immunization with the four-component vaccine resulted in the reduction of tumor size 
in mice inoculated with murine MO5 cancer cells, protection of mice from lethal cancer cell challenge, and inhibition of pre-established MO5 tumor growth.

44. Ragupathi G, Meyers M, Adluri S, Howard L, Musselli C, Livingston PO. Induction of antibodies against GD3 ganglioside in melanoma patients by vaccination with GD3-lactone-KLH conjugate plus immunological adjuvant QS-21. Int J Cancer 2000;85:659-666. [PubMed: 10699946]

45. Ragupathi G, Livingston PO, Hood C, Gathuru J, Krown SE, Chapman PB, Wolchok JD, Williams LJ, Oldfield RC, Hwu WJ. Consistent antibody response against ganglioside GD2 induced in patients with melanoma by a GD2 lactone-keyhole limpet hemocyanin conjugate vaccine plus immunological adjuvant QS-21. Clin Cancer Res 2003;9:5214-5220. [PubMed: 14614001]

46. Pan Y, Chefalo P, Nagy N, Harding C, Guo Z. Synthesis and immunological properties of N-modified GM3 antigens as therapeutic cancer vaccines. J Med Chem 2005;48:875-883. [PubMed: 15689172]

- This paper reported that $\mathrm{N}$-phenylacetyl modification of neuraminic acid of TACAs could result in vaccines that induced strong, durable and specific T cell-mediated immunity.

47. Liu T, Guo Z, Yang Q, Sad S, Jennings HJ. Biochemical engineering of surface alpha 2-8 polysialic acid for immunotargeting tumor cells. J Biol Chem 2000;275:32832-32836. [PubMed: 10976100]

48. Bertozzi CR, Kiessling LL. Chemical glycobiology. Science 2001;291:2357-2364. [PubMed: 11269316]

49. Wu J, Guo Z. Improving the antigenicity of sTn antigen by modification of its sialic acid residue for development of glycoconjugate cancer vaccines. Bioconjug Chem 2006;17:1537-1544. [PubMed: 17105234]

50. Chefalo P, Pan Y, Nagy N, Guo Z, Harding CV. Efficient metabolic engineering of GM3 on tumor cells by N-phenylacetyl-D-mannosamine. Biochemistry 2006;45:3733-3739. [PubMed: 16533056]

51. Wang Q, Zhang J, Guo Z. Efficient glycoengineering of GM3 on melanoma cell and monoclonal antibody-mediated selective killing of the glycoengineered cancer cell. Bioorg Med Chem 2007;15:7561-7567. [PubMed: 17892942] •• This paper described that cancer cells could be efficiently engineered to express unnatural sialo-TACA analogues upon treatment with low $\mu \mathrm{M}$ concentrations of ManNPhAc and the unnatural TACA analogue-induced antisera and/or antibodies showed strong and specific complement-dependent cytotoxicity to ManNPhAc-treated cancer cells.

52. Bitton RJ, Guthmann MD, Gabri MR, Carnero AJ, Alonso DF, Fainboim L, Gomez DE. Cancer vaccines: an update with special focus on ganglioside antigens. Oncol Rep 2002;9:267-276. [PubMed: 11836591]

53. Zou W, Borrelli S, Gilbert M, Liu T, Pon RA, Jennings HJ. Bioengineering of surface GD3 ganglioside for immunotargeting human melanoma cells. J Biol Chem 2004;279:25390-25399. [PubMed: 15047693]

54. Fukuda M. Possible roles of tumor-associated carbohydrate antigens. Cancer Res 1996;56:22372244. [PubMed: 8625291]

55. Takano R, Muchmore E, Dennis JW. Sialylation and malignant potential in tumour cell glycosylation mutants. Glycobiology 1994;4:665-674. [PubMed: 7881181] 


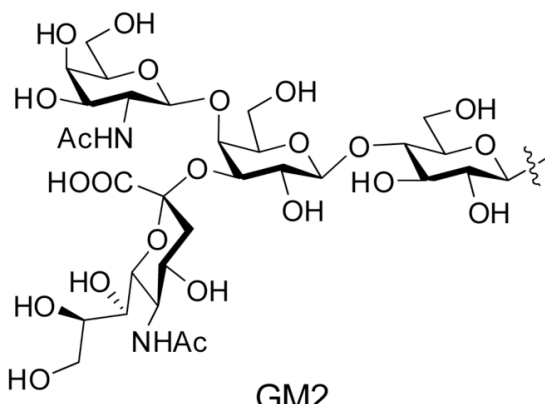

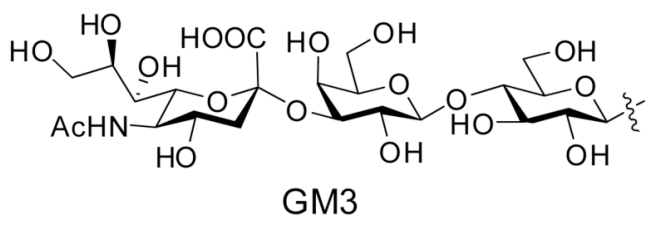

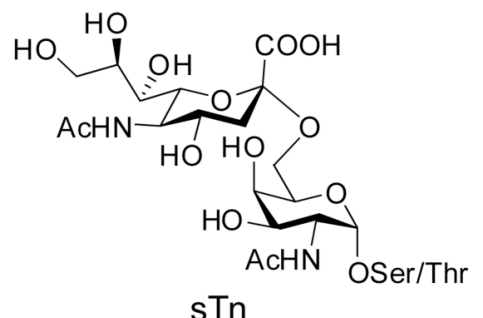
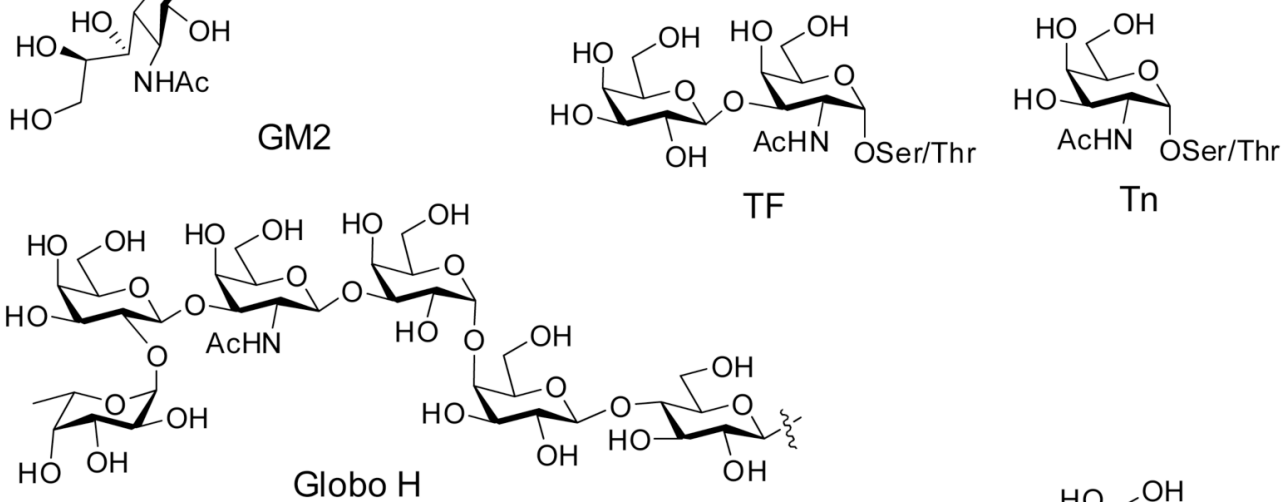

$\mathrm{Tn}$
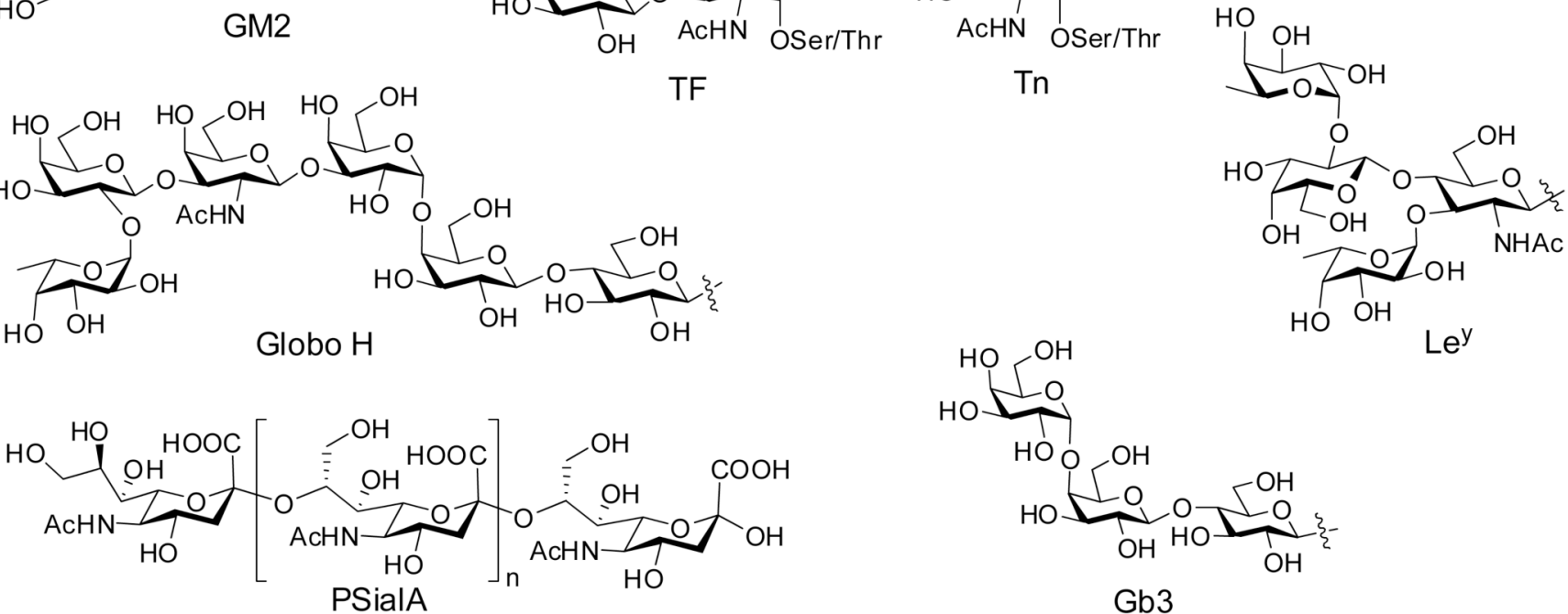

Gb3

Figure 1.

Structures of some representative TACAs mentioned in this review. 


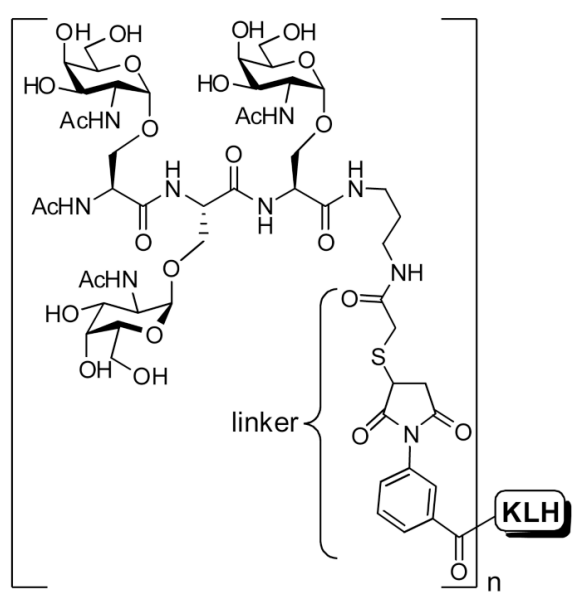

$\operatorname{Tn}(\mathrm{c})-\mathrm{KLH}$

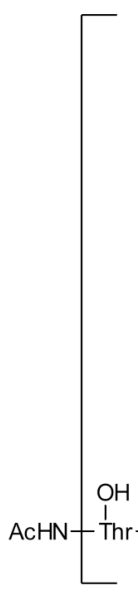

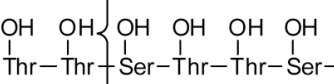

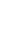

(1)
(

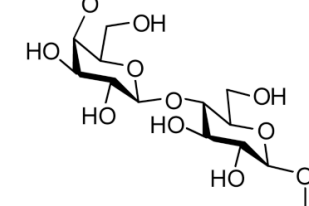

Figure 2.

Structures of representative semi-synthetic mono-epitopic clustered conjugate vaccines. 


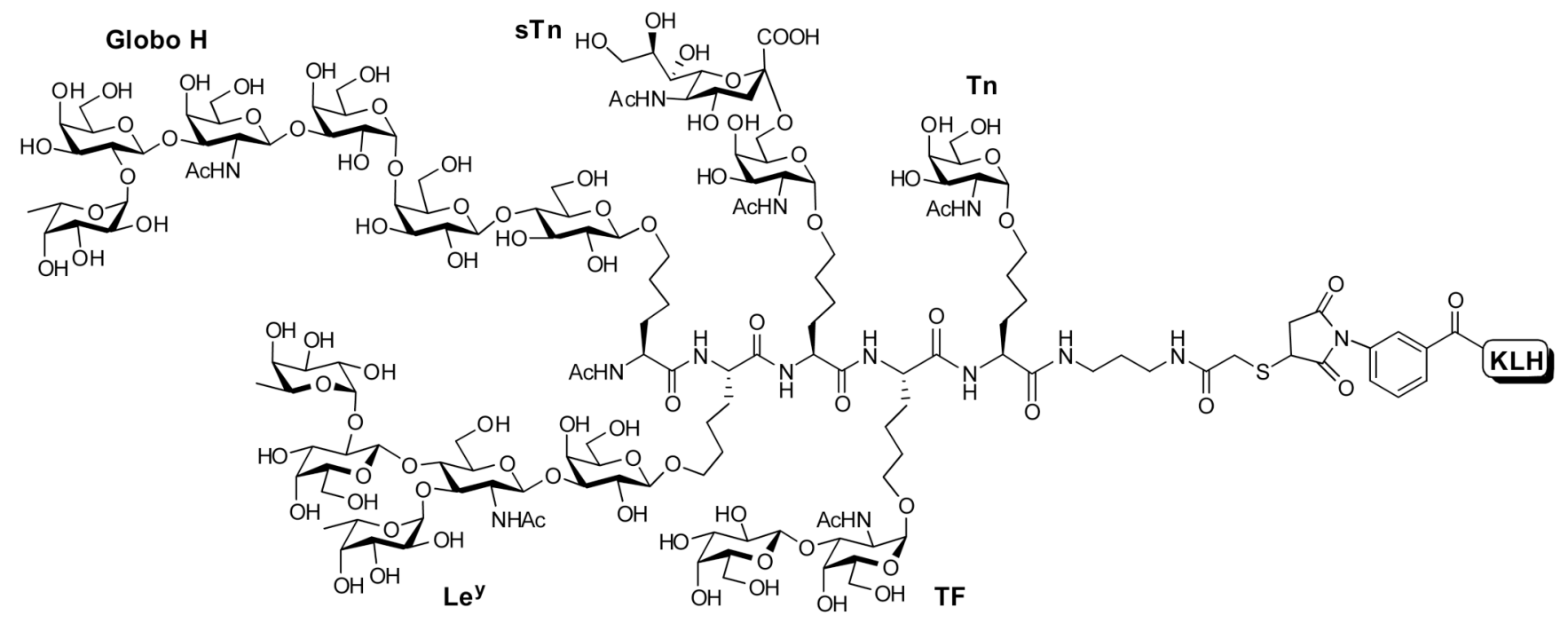

Figure 3.

Structure of a representative semi-synthetic multi-epitopic conjugate vaccine. 

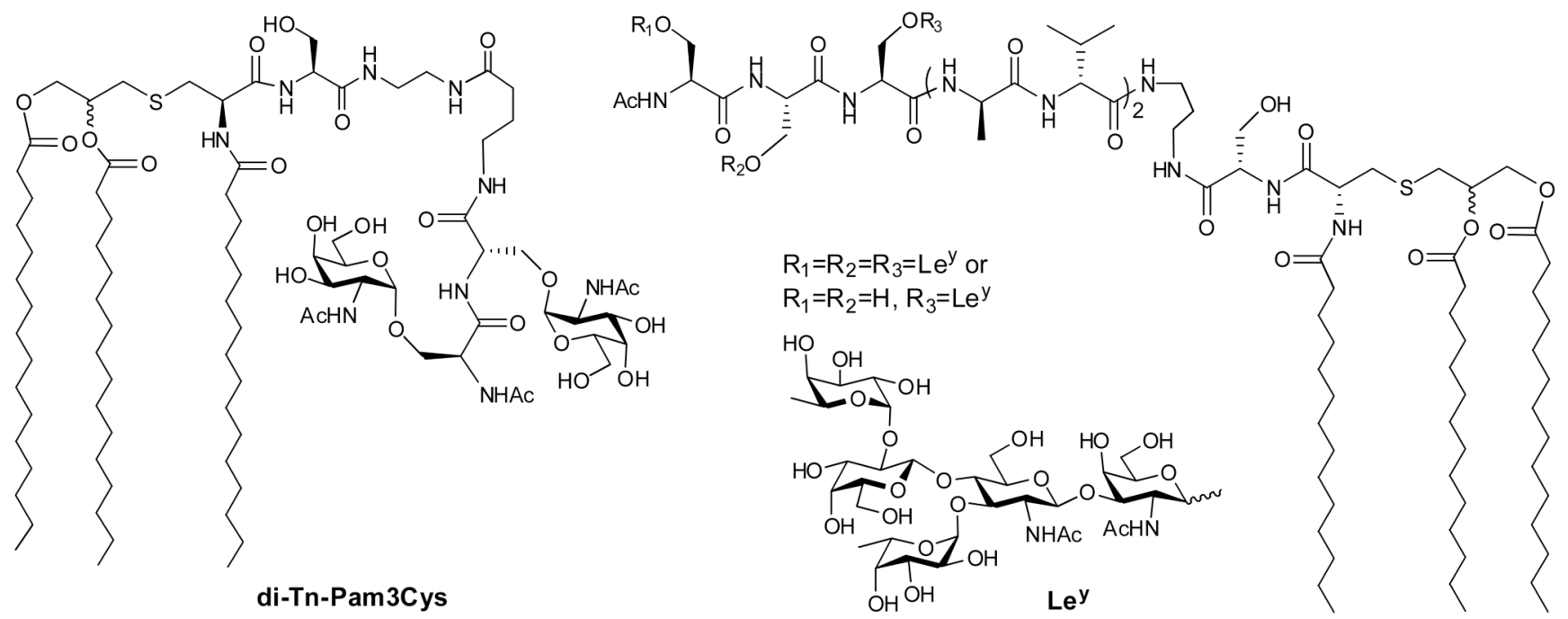

Figure 4.

Structures of representative Pam2Cys-based fully synthetic two-component vaccines. 

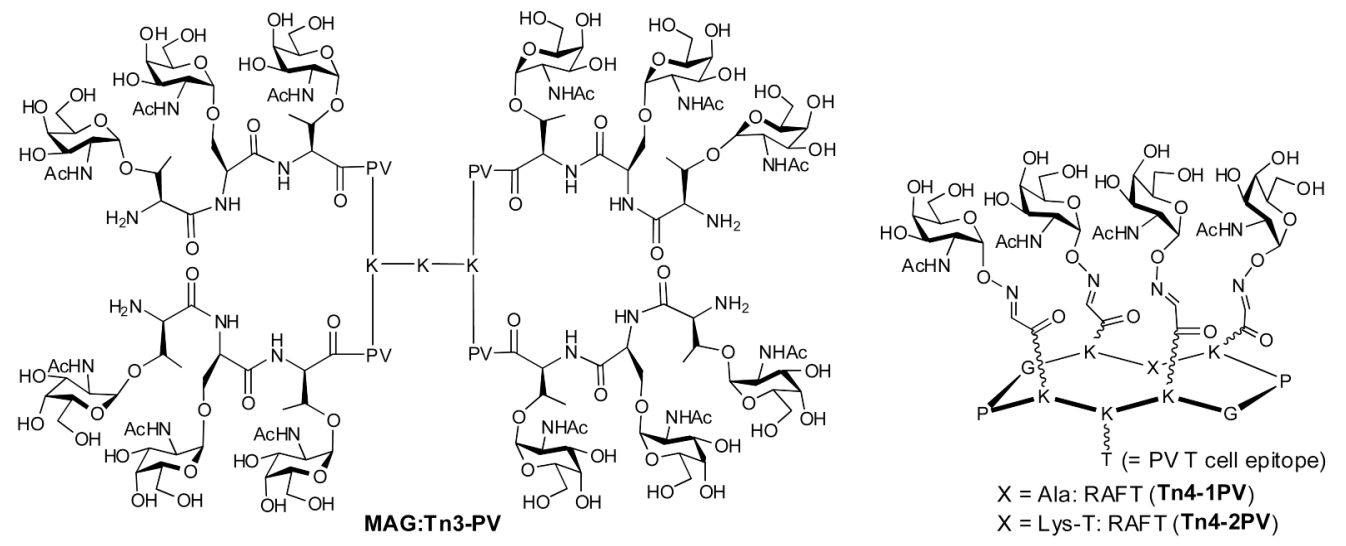

Figure 5.

Structures of representative fully synthetic two-component glycopeptide vaccines. 

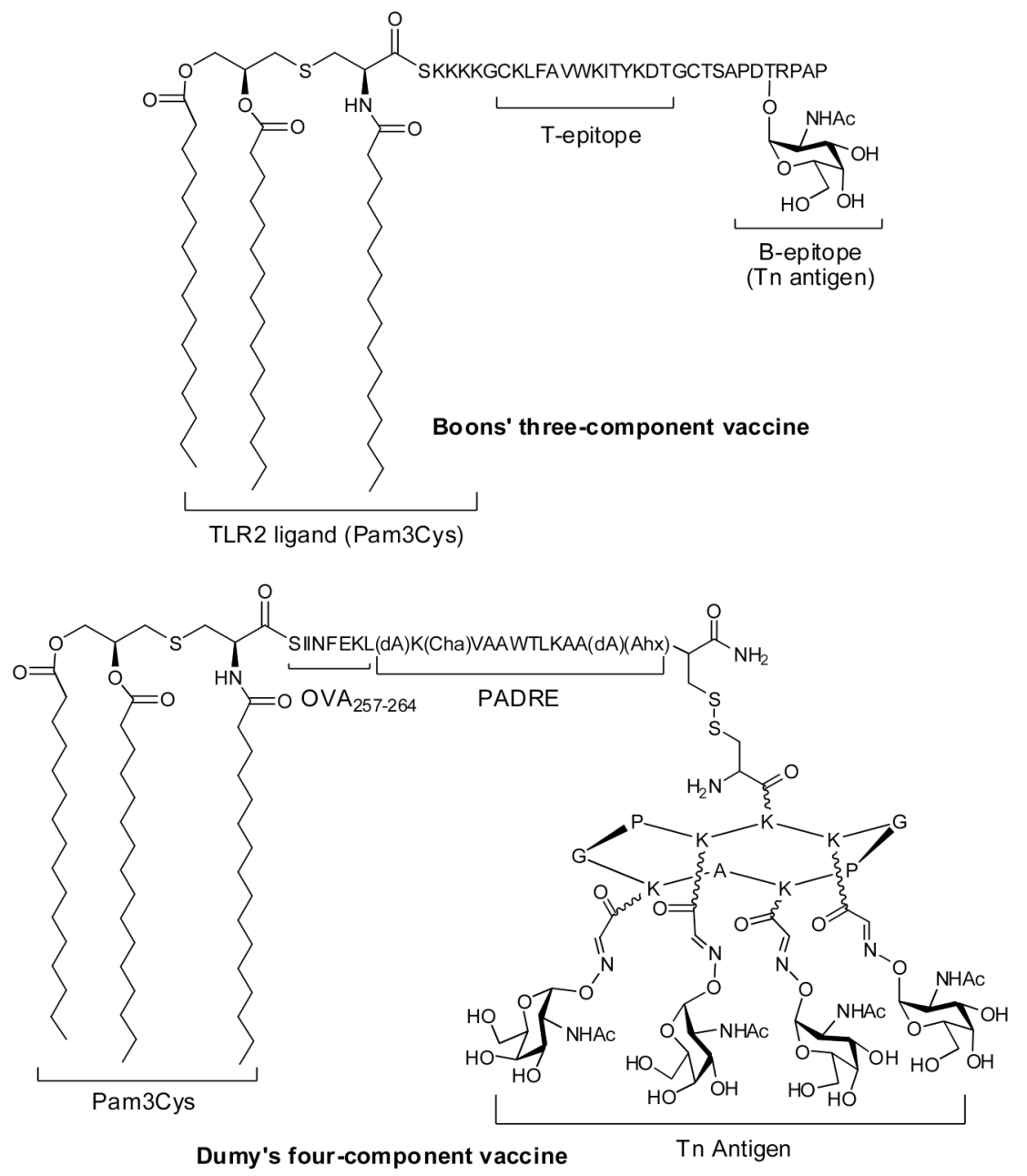

Figure 6.

Fully synthetic three-component and four-component cancer vaccines. 


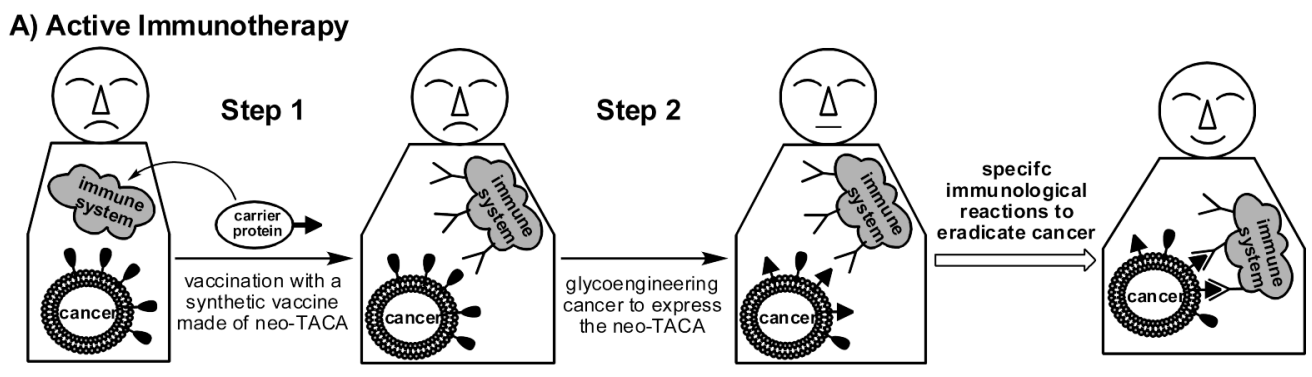

B) Passive Immunotherapy

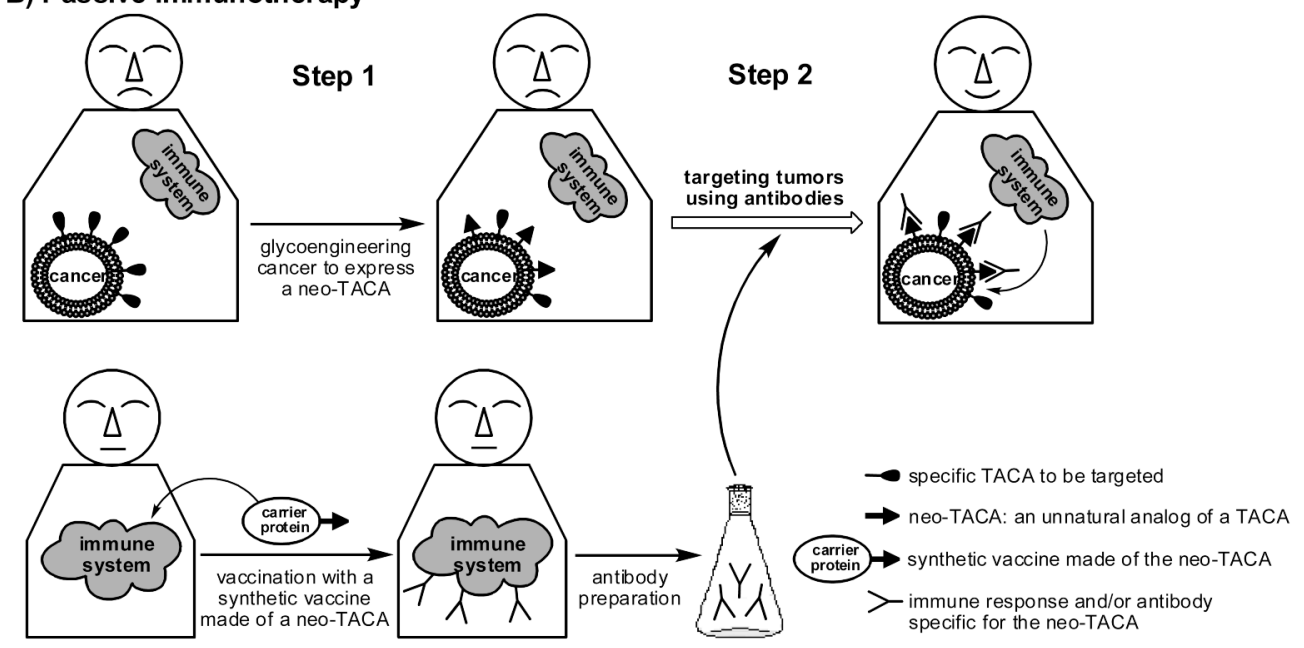

Figure 7.

New cancer immunotherapy based on cancer cell glycoengineering. 


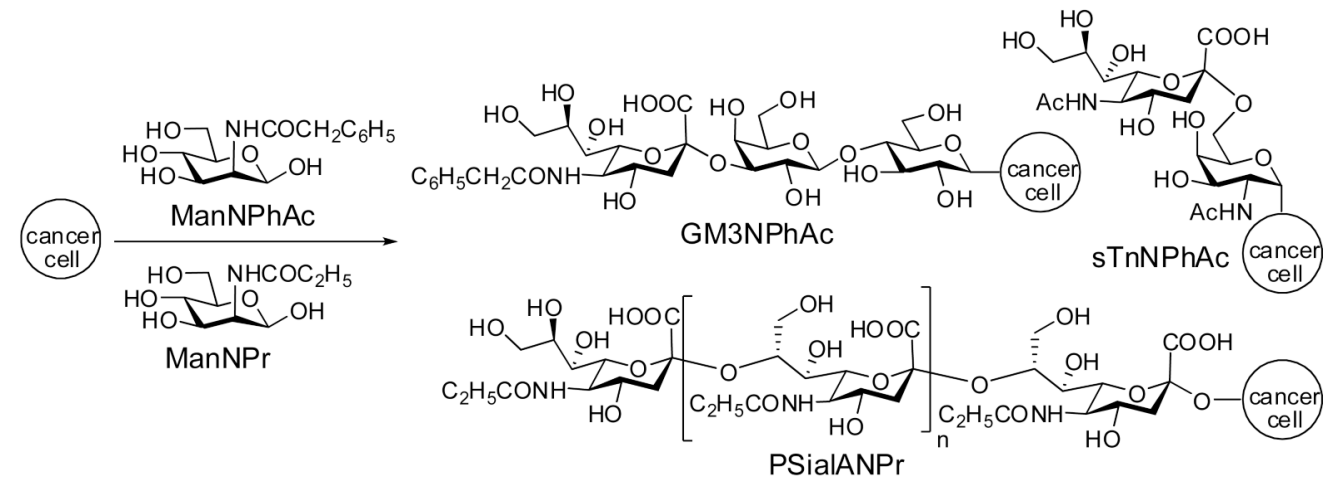

Figure 8.

Structures of mannosamine derivatives used as precursors for cancer glycoengineering and of the unnatural TACA analogues expressed on cancer cells. 